\title{
Hryniak A. The peculiarities of contractual regulation of private legal relations
}

The article examines various aspects of contractual regulation of private legal relations, that allowed to study civil law as a regulator of property relations in its dynamics at all stages. The shifting of the emphasis from the legislative regulation of legal relations between their participants in the direction of their contractual definition in the field of private legal relations is stated, since the legislative regulation is aimed at the regulation of private legal relations, and contractual - at their organization and formation. Contract regulation in the mechanism of legal regulation of private legal relations occupies a special place by forming a separate subsystem - a set of elements that form in its systemic unity the mechanism of contractual regulation of private legal relations.

Keywords: civil legal contract, contractual regulation, private legal relations, mechanism of legal regulation, freedom of contract, principles of contractual regulation.

\section{УМОВИ ДОГОВОРУ ПІДЯДУ НА ПРОВЕДЕННЯ ПОШУКОВИХ РОБІТ}

\section{Гуцуляк В. К.,}

кандидат юридичних наук, начальник департаменту з розслідування особливо важсливих справ у сфері економіки Генеральної прокуратури України

В статті аналізуються питання, пов'язані з укладенням договору підряду на проведення пошукових робіт. Особлива увага акиентується на таких умовах договору підряду на проведення пошукових робіт, як предмет, ціна та строк. Встановлено, щио ијіна та строк за договором на проведення пошукових робіт не є його істотною умовою, якщо інше сторони не передбачили між собою. Тобто сторони можуть $і$ не передбачати ціну проведених пошукових робіт, а у разі виникнення спору таке визначення буде проведено судом, який уже на власний розсуд встановлює иіну або спосіб ї̈ визначення. Однак, якще хоча б однією зі сторін піднімалося питання внесення до договору умови про циіну або ж сторони не досягли згоди щчодо неї, то така умова визнається істотною. Обтрунтовано, що у зв 'язку із тим, що більшість пошукових робіт є складними та об'єднують в собі різні етапи (від підготовчого до проміжного та завершального), в договорі сторони можуть передбачити терміни початку $i$ закінчення робіт, а окремі проміжні етапи дочільно погоджувати в календарному плані, що є додатком до договору, та найбільш повно відображати поетапне виконання підрядником свойх зобов'язань за договором підряду на проведення пошукових робіт.

Ключові слова: договір підряду на проведення пошукових робіт, істотні умови договору, предмет договору, ціна договору, строк договору, укладення договору.

Виходячи зі змісту ч. 2 ст. 631 ЦК України, договір набирає чинності з моменту його укладення, хоча сторони мають право встановити, що умови укладеного ними договору можуть застосовуватися до відносин, що виникли ще до його укладення. Це можуть бути фактичні відносини, які склалися між сторонами. У цих випадках сторони, як правило, юридично оформлюють свої відносини шляхом укладення договору підряду на проведення пошукових робіт, який поширює свою дію на вже існуючі відносини. Відповідно до змісту ст. 627 ЦК України фізичні та юридичні особи самостійно вирішують питання про укладення договору, про вибір контрагента, а також можуть вільно визначати умови майбутнього договору.

Із аналізу вищенаведених загальних положень ЦК України можна зробити висновок, що договір підряду на проведення пошукових робіт укладається шляхом пропозиції однієї сторони укласти договір (оферта) і прийняття пропозиції (акцепт) іншою стороною. Така оферта повинна містити істотні умови договору підряду на проведення пошукових робіт і виражати намір особи, яка ії зробила, вважати себе зобов'язаною у разі ії прийняття. Законодавець не встановлює будь-яких обмежень 3 приводу того, хто може бути оферентом за цим різновидом договору підряду.

У висловленій пропозиції замовник визначає умови майбутнього договору, що в подальшому проходитимуть погодження із підрядником. Зазвичай замовник в оферті передбачає ті умови, які $\epsilon$ для нього істотними. Відповідь особи, якій адресована пропозиція укласти договір підряду на проведення пошукових робіт, про іiї прийняття повинна повністю погоджуватись з умовами, що запропоновані їй в оферті, і не містити жодних застережень. Тобто договір вважається укладеним, якщо сторони в належній формі досягли згоди з усіх істотних його умов.

Аналізуючи умови договору підряду на проведення пошукових робіт, вважаємо, що до них слід відносити такі варіації поведінки сторін, які ними обумовлюються, та, як наслідок, спричиняють виникнення у них відповідних прав і обов'язків. Тобто як положення, що імперативно вимагаються для їх встановлення законодавцем у $\$ 4$ гл. 61 ЦК, так і положення, що пропонуються до узгодження однією зі сторін договору, адже і в першому, і в другому випадках сторонам необхідно конкретизувати 
свою поведінку. Практичне значення розгляду теоретичних положень про умови будь-якого типу договірних зобов'язань, у тому числі й досліджуваного нами різновиду групи договорів 3 виконання робіт, полягає у двох моментах: 1) досягнення у належній формі домовленості сторін щодо істотних умов договору тягне за собою набрання сили таким договором; 2) визначені законодавством i домовленістю сторін умови договору породжують відповідні права та обов'язки учасників даного договірного правовідношення [1]. Отже, детальніше зупинимося на питанні встановлення мінімально необхідних умов договору підряду на проведення пошукових робіт.

Істотними умовами договору, як передбачено в ст. 638 ЦК України, є умова про предмет договору, умови, що визначені законом як істотні або є необхідними для договорів цього виду, а також усі ті умови, щодо яких за заявою хоча б однієї зі сторін має бути досягнуто згоди. Тобто законодавець виділяє три групи істотних умов договору: а) умови, визнані істотними законом; б) умови, що є необхідними для договорів конкретного виду; в) умови, щодо яких за заявою хоча б однієї зі сторін має бути досягнуто згоди.

Зупинимось на такій істотній умові договору підряду на проведення пошукових робіт, як предмет. Насамперед доцільно зазначити, що, зважаючи на триваючу в юридичній літературі дискусію щодо предмета договору підряду, ми схиляємось до аргументів тих вчених, які предметом договорів підряду визначають результат роботи підрядника [2; 3], оскільки саме по собі виконання замовлення не може бути предметом договору хоча б тільки через те, що робота, як правило, виконується підрядником самостійно. На нашу думку, хоча й законодавець в 4 гл. 61 ЦК і не дотримується єдності в термінології, вказуючи в одному випадку тільки на роботу як на предмет договору на проведення пошукових робіт, а в іншому - на їі результат, предметом цього договору є звіт про результати пошукових робіт, цілий комплекс технічної документації, зміст якої становлять техніко-економічні обгрунтування доцільності проведення робіт, креслення, пояснювальні записки, технічні завдання та інші відомості, необхідні для якісного проведення наступних за пошуковими (проектних) робіт та отримані в результаті робіт дані, тобто матеріалізована форма, що опосередковує виконану роботу.

Наприклад, у ДБН А.2.1-1-2014 «Інженерні вишукування для будівництва» (п. 5.3.1) передбачено, що результатом інженерно-геодезичних вишукувань $є$ науково-технічний звіт. Текстова частина такого звіту повинна містити: а) загальні відомості - мету інженерно-геодезичних вишукувань, підставу для виконання робіт, склад та обсяги виконаних робіт, строки їх виконання, відомості про виконавців; б) відомості про методи та технології виконання робіт - систему координат та висот, відомості про наявність та характеристику існуючих геодезичних мереж, методи побудови опорної (знімальної) геодезичної мережі, методи створення інженерно-топографічних планів або геодезичних вимірювань, методи виконання камеральних робіт, характеристику точності та детальності робіт, відомості про застосоване геодезичне обладнання та програмне забезпечення; в) результати контрольних вимірювань (за наявності); г) висновки - стислі результати робіт та їх оцінка, відомості про повноту і якість, відповідність вимогам технічного завдання, чинним нормативним документам, рекомендації щодо проведення подальших інженерно-геодезичних вишукувань.

Графічна частина технічного звіту має містити: а) картограму (ситуаційний план) 3 позначенням меж ділянки вишукувань, розграфленням аркушів та орієнтуванням відносно населених пунктів (вулиць); б) схеми створеної планово-висотної опорної, або знімальної, геодезичної мережі; в) інженернотопографічні плани у цифровій (ІЦММ) або графічній формі; г) плани та профілі підземних та надземних (за необхідності) інженерних комунікацій; г) графіки (або плани) та таблиці результатів спостережень за осіданням та деформаціями будівель, споруд, земної поверхні; д) інженерно-топографічні плани прибережних частин та акваторій, повздовжні та поперечні профілі.

Отже, результати пошукових робіт повинні бути достовірними і достатніми для встановлення проектних значень параметрів та інших проектних характеристик і мають передаватися замовнику у вигляді технічного звіту про виконані роботи, оформленого відповідно до вимог нормативних документів і державних стандартів. Крім того, на практиці прийнято вимагати від підрядника звітні матеріали щодо усіх етапів робіт, що містять попередні результати, і заключний звіт із вмістом опису технологічних процесів, використаних в ході проведення пошукових робіт, а також комплексної інтерпретації отриманих результатів. Звіт, як правило, надається на паперовому носії в узгодженій сторонами кількості примірників і, 3 огляду на його обсяг, на електронному носії в зручному для замовника форматі.

Наступною важливою умовою, що потребує погодження між сторонами договору підряду на проведення пошукових робіт, є ціна. Зважаючи на те, що у спеціальних положеннях § 4 гл. 61 ЦК України відсутні вказівки щодо порядку визначення ціни, а в ч. 2 ст. 887 ЦК закріплено можливість застосування до цих правовідносин загальних положень ЦК, можемо констатувати поширення на досліджувані правовідносини 3 проведення пошукових робіт положень ст. 843 ЦК України. Зі змісту цієї статті випливає, що ціна може бути визначена: а) безпосередньо в договорі на проведення пошукових робіт або ж шляхом закріплення в ньому способу визначення ціни; б) у кошторисі, який в такому випадку є додатком до договору та повинен містити перелік затрат на проведення такого роду робіт (ст. 844 ЦК); в) у рішенні суду на основі цін, що звичайно застосовуються за аналогічні роботи.

Найбільш поширеним у практиці укладення договору підряду на проведення пошукових робіт є такий спосіб закріплення ціни, як складання кошторису. Фактично кошторис є доволі зручним 
способом закріплення сторонами домовленостей щодо ціни пошукових робіт, оскільки ще на стадії пошуку контрагента замовником останній в змозі оцінити кінцеву вартість усіх робіт, а також склад робіт, внесений до кошторису. Так, професійно складений кошторис надає можливість замовнику оцінити обгрунтування викладу всіх матеріальних витрат, прибутку, амортизації, необхідних податкових платежів підрядника та інших показників, що визначають вартість робіт. На практиці доволі часто трапляється, що договір підряду на проведення пошукових робіт укладається на стадії, коли технічне завдання замовника в повному обсязі ще не сформовано (особливо у випадках, коли технічне завдання розробляється замовником), в такому випадку кошторис може бути складено лише на основі приблизних показників. Законодавець цілком доречно допускає таку можливість, закріпивши в ч. 2 ст. 844 ЦК України тезу, що кошторис на виконання робіт може бути приблизним або твердим.

Сторони можуть за погодженням між собою вносити зміни до твердого кошторису. Зокрема, у разі істотного зростання після укладення договору вартості матеріалу, устаткування, які мали бути надані підрядником, а також вартості послуг, що надавалися йому іншими особами, підрядник має право вимагати збільшення кошторису. У разі відмови замовника від цього підрядник має право вимагати розірвання договору. Проте підрядник не має права вимагати збільшення твердого кошторису, а замовник - його зменшення у разі, якщо на момент укладення договору підряду не можна було передбачити повний обсяг робіт або необхідні для цього витрати (ч. 5 ст. 844 ЦК) [4].

Цікавою особливістю законодавчого закріплення у ЦК України положень про ціну та кошторис $є$ те, що ціна роботи та кошторис визначаються в окремих статтях (843 та 844 відповідно), що свідчить про цілком правильне сприйняття цих двох термінів як неідентичних, оскільки кошторис - це форма вираження ціни, тобто документ, який містить відомості про неї. Ціна ж може бути зафіксована в договорі без складання кошторису. Таке розмежування поняття кошторису і ціни роботи значно полегшує розуміння та тлумачення цих норм на практиці. Тобто А. Б. Гриняк цілком слушно під ціною договору підряду пропонує розуміти грошову суму, що належить до виплати підряднику за виконану ним роботу [5].

Як видається, зазначений загальний підхід до визначення ціни роботи за аналогією закону поширює свою дію і на відносини за договором підряду на проведення пошукових робіт, адже законодавець у ч. 2 ст. 887 ЦК передбачив таку можливість за умови, якщо відсутні інші законодавчі застереження. Аналіз § 4 гл. 61 ЦК України, Закону України «Про регулювання містобудівної діяльності» та інших підзаконних нормативно-правових актів надає можливість зробити висновок про відсутність таких застережень. Більше того, наявність кошторису дозволить замовнику об'єктивно оцінювати вартість, запропоновану підрядником, особливо в умовах укладення договору шляхом проведення торгів.

Зважаючи на вищенаведене, вважаємо, що ціна за договором підряду на проведення пошукових робіт може бути визначена як у твердому (незмінному на весь період виконання пошукових робіт), так і в приблизному (із закріпленням можливості внесення до нього змін) кошторисі. У випадку визначення ціни у приблизному кошторисі у договорі варто чітко передбачити випадки перерахунку вартості пошукових робіт. Водночас ціна за договором на проведення пошукових робіт за державним замовленням або ж замовленням територіальних громад $є$ твердою і не може змінюватися в ході його виконання.

Протилежного висновку про неможливість застосування положень ст. 843 ЦК України до договірних відносин щодо проведення проектних та пошукових робіт доходить I. С. Лукасевич-Крутник. На думку дослідниці, типове проектування, для якого можна визначити ціни, що звичайно застосовуються за аналогічні роботи, сьогодні не має попиту і практично не використовується. Замовники вимагають індивідуального підходу та оригінальності у розробленні проектів. Та й пошукові роботи в кожному конкретному випадку відрізняються, що обумовлюється місцем розташування земельної ділянки тощо. Тому застосування «цін, що звичайно застосовуються за аналогічні роботи» до пошукових та (або) проектних робіт не є характерним. Ціна виконання пошукових та (або) проектних робіт визначається індивідуально в кожному конкретному випадку. Ще одним аргументом на користь того, що ціна повинна бути визначена у договорі підряду на проведення проектних та пошукових робіт, $\epsilon$ те, що в більшості випадків такі договори є господарськими. А в господарських договорах в силу ч. 3 ст. 180 ГК України сторони у будь-якому разі зобов'язані погодити ціну договору. Тому, на думку дослідниці, умова про ціну повинна розглядатись як істотна умова договору підряду на проведення проектних та пошукових робіт [6].

На нашу думку, наведені аргументи не є безспірними, оскільки в кожному конкретному випадку суд може залучити незалежних експертів та, базуючись на їх висновку (який однозначно буде проведений на основі аналізу технічного завдання, інших вихідних даних, етапів проведення робіт тощо), винести відповідне рішення з урахуванням індивідуального підходу та оригінальності у розробленні результатів пошукових робіт. Щодо такого аргументу, як закріплення в ГК України ціни як істотної умови господарського договору під загрозою визнання його неукладеним, хочеться зазначити, що такий категоричний підхід аж ніяк не спрямований на стабільність цивільного обороту, оскільки у ст. 632 ЦК України закладено механізм встановлення ціни на випадок, коли ціна в договорі не встановлена. Більше того, зазначений у ГК України підхід неодноразово піддавався критиці як такий, що суперечить загальним засадам договірного права навіть представниками науки господарського права [7], на думку яких ціна у господарських договорах повинна визнаватися істотною лише для тих випадків, коли вона не може визначатися у інший спосіб (наприклад, при укладенні ліцензійних договорів на використання об’єктів 
інтелектуальної власності або договорів комерційної концесії з огляду на унікальність нематеріальних об’єктів - результатів творчої діяльності) [8].

Виходячи з цього, вважаємо за доцільне підтримати висловлену в юридичній літературі позицію, що у тих випадках, коли в господарському договорі ціна не була погоджена, доцільно було б іти шляхом переважного застосування до господарських договорів більш ліберальних положень ЦК [9], виклавши перше речення ч. 2 ст. 189 ГК України у запропонованій А. Б. Гриняком редакції: «Ціна $\epsilon$ істотною умовою господарського договору лише у випадках, коли вона не може бути визначена в інший спосіб на основі звичайних иуін, щяо склалися на аналогічні товари, роботи або послуги на момент укладення договору» [5].

Отже, вважаємо, що ціна за договором на проведення пошукових робіт не $є$ його істотною умовою, якщо інше сторони не передбачили між собою. Тобто сторони можуть і не передбачати ціну проведених пошукових робіт, а у разі виникнення спору таке визначення буде проведено судом, який уже на власний розсуд встановлює ціну або спосіб їі визначення. Однак, якщо хоча б однією зі сторін піднімалося питання внесення до договору умови про ціну або ж сторони не досягли згоди щодо неї, то така умова визнається істотною.

Аналізуючи таку умову договору підряду на проведення пошукових робіт, як строк виконання пошукових робіт, слід зазначити, що, як і щодо ціни, якихось спеціальних положень щодо цієї умови законодавець у § 4 гл. 61 ЦК України не визначив. Натомість, виходячи зі змісту загальних положень ст. 846 ЦК України, строки виконання роботи або ії окремих етапів встановлюються у договорі. Якщо у договорі підряду строки не встановлені, підрядник зобов'язаний виконати роботу, а замовник має право вимагати iї виконання у розумні строки, відповідно до суті зобов'язання, характеру та обсягів роботи та звичаїв ділового обороту. Тобто строки в цивільних правовідносинах відіграють важливу роль, оскільки саме вони упорядковують цивільний оборот, стабілізують цивільні відносини, сприяють якісному задоволенню потреб фізичних та юридичних осіб, забезпечують своєчасний захист цивільних прав [10].

У регулюванні підрядних договірних відносин використовуються різні види строків і термінів. Загалом же строки проведення пошукових робіт визначаються датами їх початку та закінчення, тобто певними термінами. В юридичній літературі, виходячи із різних критеріїв, строки в підрядних відносинах поділяють на: а) основні (строки, які безпосередньо впливають на своєчасне виконання робіт та передання їх результату); б) допоміжні (строки передачі проектно-кошторисної документації та документації про дозвіл відповідних органів на проведення робіт) [11]; в) імперативні; г) диспозитивні [12]; г) строки виконання роботи; д) строки прийняття роботи; е) гарантійні строки; є) строки виявлення неналежної якості роботи; ж) строки позовної давності для вимог, пропонованих у зв'язку з неналежною якістю роботи; з) строки служби; и) пільгові строки [5].

Аналізуючи закріплений у ч. 2 ст. 846 ЦК України законодавчий підхід щодо визначення права замовника вимагати виконання робіт, якщо інше не передбачено домовленістю, у розумні строки, доходимо висновку, що визначити розумний строк при виникненні спору між сторонами можна лише в судовому порядку. Як видається, такий законодавчий підхід неодноразово виправдовував себе у практиці проведення складних пошукових робіт, в яких не завжди можна спрогнозувати кінцевий термін завершення робіт, погодження всіх документів із органами місцевого самоврядування тощо. Зважаючи на це, законодавець цілком слушно не визначив строк як істотну умову договору підряду на проведення пошукових робіт, залишивши це на розсуд сторін, які вправі в договорі погоджувати такі строки та винятки, за яких сторони мають право відступати від них.

Зважаючи на те, що більшість пошукових робіт є складними та об'єднують в собі різні етапи (від підготовчого до проміжного та завершального), в договорі сторони можуть передбачити терміни початку і закінчення робіт, а окремі проміжні етапи доцільно погоджувати в календарному плані, що є додатком до договору, та найбільш повно відобразити поетапне виконання підрядником своїх зобов'язань за договором підряду на проведення пошукових робіт. Як видається, поетапне проведення пошукових робіт є основоположним принципом їх планування і організації. У випадку проведення пошукових робіт для будівництва воно забезпечує нерозривний зв'язок результатів пошукових робіт і будівельного проектування. Оскільки пошукові роботи є комплексним виробничим процесом, то їх етапи можуть встановлюватися як для пошукових робіт в цілому, так і для окремих їх видів. Можливість поетапного виконання такого роду робіт на законодавчому рівні закріплено у п. 1 ч. 1 ст. 889 ЦК України, за якою замовник зобов' язаний сплатити підрядникові встановлену ціну після завершення усіх робіт чи сплатити ii частинами після завершення окремих етапів робіт або в іншому порядку, встановленому договором або законом.

Окремо в договорі може бути погоджена умова про передання замовником технічного завдання на проведення пошукових робіт або інших вихідних даних, необхідних для проведення таких робіт. Зважаючи на те, що законодавець, вказавши на необхідність погодження такої умови в 44 гл. 61 ЦК України, загалом не передбачив чітких вимог щодо строків, форми, переліку таких даних, можемо зробити висновок про небажання законодавця втручатись у погодження таких умов та доцільність погодження такої інформації безпосередньо в договорі. Передача технічного завдання тісно пов'язана 
із загальним строком виконання робіт, адже невиконання цієї умови може спричинити неможливість виконання підрядником своїх зобов'язань. Разом із тим вищезазначену умову недоцільно відносити до істотних умов договору підряду на проведення пошукових робіт.

Щодо таких умов, як мета використання замовником результатів пошукових робіт та конфіденційність, то, як слушно зазначає I. С. Лукасевич-Крутник, такі умови можуть стати істотними, якщо за заявою хоча б однієї сторони досягнуто згоди про визнання їх такими в умовах договору [6, с. 96].

Підсумовуючи, можемо зазначити, що процедура укладення договорів підряду на проведення пошукових робіт повністю відповідає загальному порядку укладення цивільно-правових договорів. Разом із тим у сфері проведення пошукових робіт можна виокремити: а) організаційну стадію укладення договору підряду на проведення пошукових робіт, в якій як складовий елемент можна виділити інформаційну підстадію, на якій шляхом обміну інформацією проводиться пошук підрядника, готується орієнтовний проект договору, встановлюються правила договірного процесу; б) стадію погодження умов договору, на якій перевіряється дієздатність сторін договору, можливості підрядника щодо проведення пошукових робіт, наявність необхідних дозволів тощо та замовника щодо ії оплати; в) стадію укладення договору, на якій волевиявленням сторін надається необхідна форма.

\section{СПИСОК ВИКОРИСТАНОЇ ЛІТЕРАТУРИ:}

1. Ярошевська Г. М. Договір про надання юридичних послуг: дис. ... канд. юрид. наук: 12.00.03. Харків, 2014. С. 99.

2. Договори з виконання робіт в цивільному праві України: проблеми теорії і практики: монографія / За заг. ред. А. Б. Гриняка. К.: НДІ приватного права і підприємництва імені академіка Ф. Г. Бурчака НАПрН України, 2015. С. 77.

3. Пленюк М. Д. Результат робіт як істотна умова договору будівельного підряду // Юридична Україна. 2013. № 10. С. 62.

4. Срмолаєв А. Договір підряду: нарахування та утримання // Податки та бухгалтерський облік. 2002. № 19. С. 81.

5. Гриняк А. Б. Теоретичні засади правового регулювання підрядних зобов'язань у цивільному праві України: монографія. К.: НДІ приватного права і підприємництва НАПрН України, 2013. C. $137,132,139-140$.

6. Лукасевич-Крутник I. С. Договір підряду на проведення проектних та пошукових робіт: монографія. Тернопіль: ВПЦ «Економічна думка ТНЕУ», 2012. С. 90-91, 96.

7. Мілаш В. Істотні умови договору і диспозитивність їх правового регулювання // Підприємництво, господарство і право. 2007. № 2. С. 37-38.

8. Беляневич О. А. Господарське договірне право України (теоретичні аспекти): монографія. Юрінком Інтер, 2006. C. 216.

9. Проблемні питання у застосуванні Цивільного та Господарського кодексів України / За ред. А. Г. Яреми, В. Г. Ротаня. К.: Реферат, 2005. С. 138.

10. Хащівська Н. В. Цивільно-правове регулювання строків у договорі оренди державного та комунального майна // Приватне право і підприємництво. Вип. 9, 2010 р. / Редкол.: Крупчан О. Д. (гол. ред.) та ін. К.: НДІ приватного права і підприємництва АПрН України, 2010. С. 104.

11. Пленюк М. Д. Загальна характеристика строків у підрядних договорах // Приватне право і підприємництво. Вип. 9, 2010 р. / Редкол.: Крупчан О. Д. (гол. ред.) та ін. К.: НДІ приватного права і підприємництва АПрН України, 2010. С. 106.

12. Коссак В. М. Регулювання строків у будівництві. К.: Будівельник, 1991. С. 134.

\section{Hutsulyak V. The conditions of the contract on conducting search works}

The article analyzes the issues connected with the conclusion of a contract for conducting search works. Special attention is paid to such conditions of a contract for conducting search works as a subject, price and term. It has been established that the price and term of the contract for conducting search works is not an essential condition unless otherwise is provided by the parties. That is, the parties may not include the price of the search work, and in the event of a dispute, such a determination will be carried out by a court which, at its own discretion, establishes the price or method of its determination. However, if at least one of the parties raised the issue of entering into a contract terms of the price or the parties did not reach agreement on it, then such a condition is considered essential. It is substantiated that in connection with the fact that most search works are complex and combine different stages (from preparatory to intermediate and final), in the contract parties can provide the terms of the beginning and end of works, and it is advisable to agree separate intermediate stages in the calendar plan, which is an addition to the contract, and will most fully reflect the phased implementation by the contractor of his obligations under the contract for conducting search work.

Keywords: contract for conducting search works, essential conditions of the contract, the subject of the contract, the price of the contract, the term of the contract, the conclusion of the contract. 